\title{
AVAILABILITY OF GROUND WATER FROM ALLUVIUM ALONG THE MISSOURI RIVER IN NORTHEASTERN MONTANA
}

By W. B. Hopkins and J. K. Tilstra

\section{INTRODUCTION}

The Missouri River in northeastern Montana flows eastward more than 100 miles from Fort Peck dam to the North Dakota State line. The relatively flat bottom land that borders the river within its valley averages about 3 miles in width and includes parts of Valley, Roosevelt, McCone, and Richland Counties, Mont. (See fig. 1.)

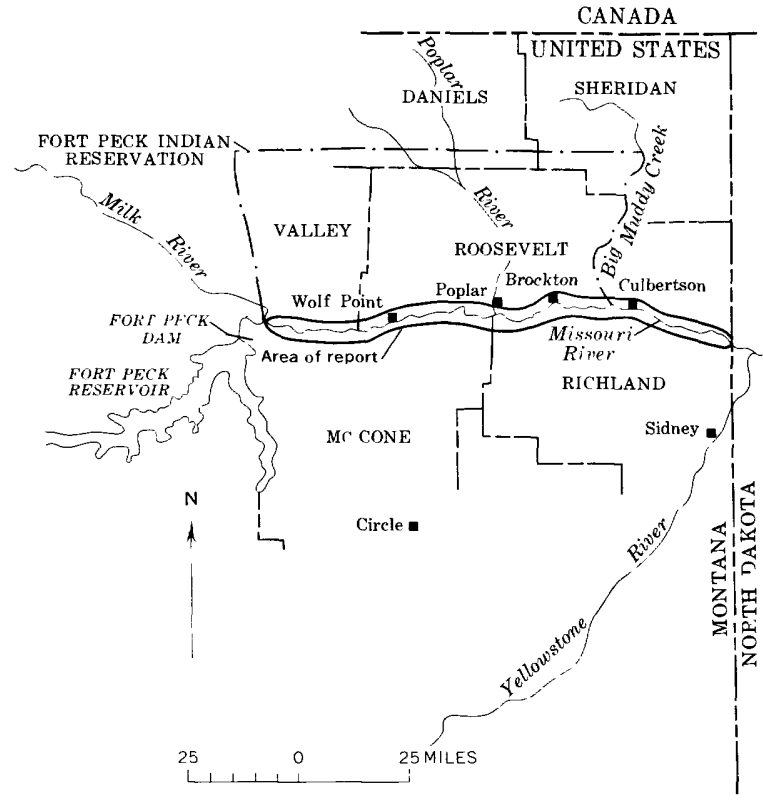

FIGURE 1.- Index map showing area of report.

The climate of northeastern Montana is semiarid and precipitation averages about 13 inches per year. The economy of the region is based primarily on agriculture, and owing to the seasonal distribution of precipitation, irrigation is necessary for satisfactory production of most crops raised in the area. Where land to be irrigated is adjacent to the river, surface water commonly is used. About 100 privately owned pumping plants take water from the Missouri or its tributaries to irrigate about 14,000 acres of bottom land. On the Fort Peck Indian Reservation two pumping stations furnish irrigation water for about 23,000 acres.

\section{Purpose of investigation}

There are many isolated tracts of arable land on both sides of the Missouri River so located that surface water for irrigation cannot be economically delivered to the land. The investigation was made to determine the feasibility of obtaining, from individual wells, as much as 2 cubic feet per second (about 900 gallons per minute) of ground water suitable for irrigation, industrial, and municipal use. To fulfill this purpose, it was necessary to determine the extent and thickness of water-bearing sand and gravel beds in the alluvial fill of the Missouri River valley and the chemcal quality of the contained water.

\section{Methods of investigation}

Test holes were drilled at approximately 1/4-mile intervals along six lines across the valley. Logs of the test holes were compared with logs of privately owned and municipal wells and used to determine the thickness and composition of the alluvium. The locations of the wells, test holes, and cross sections are shown on the map.

Aquifer tests were made to determine some of the hydrologic characteristics of the gravel aquifer within the alluvium. Chemical analyses were made of ground water from test holes and from privately owned wells. The analyses of the water samples are presented in table 2 and are shown graphically on the map. Analyses of water collected in 1947 (Swenson, 1955) from wells in the alluvium are included to supplement the more recent data. Where surface water was presumed to affect the quality of the ground water, surface-water samples were collected. Analyses of the surface water are presented in table 3 .

\section{Well-numbering system}

Wells and test holes are numbered in this report according to their location within the land subdivisions of the U.S. Bureau of Land Management. The first numeral of the well number denotes the township, the second the range, and the third the section in which the well is located. The lowercase letters a, b, c, and d, following the section number show the location of the well within the section; the first letter indicates the quarter section and the second and third indicate successive quarterings. The lowercase letters are as signed in a counterclockwise direction, beginning with "a" in the northeast quadrant. If two or more wells lie within the same 10-acre tract, appended consecutive numbers are used to identify the wells. (See fig. 2.)

\section{ACKNOWLEDGMENTS}

The cooperation of land owners, who permitted water samples to be collected from their wells, permitted use of their wells for aquifer tests, provided information about their wells, and permitted test holes to be drilled on their property, is gratefully acknowledged. The State Highway Department granted permission to drill test holes along the highway rights-of-way. County, State, and Federal officials and civic leaders in northeastern Montana were interested and very helpful in many phases of the investigation.

\section{GEOLOGIC SETTING}

The valley of the Missouri River is carved into the Bearpaw Shale, Fox Hills Sandstone, and Hell Creek 
Formations of Late Cretaceous age, and the Fort Union Formation of Paleocene age. Swenson (1955) describes the lithology and distribution of these bedrock formations in detail. The buried bedrock floor of the valley is from 1 to 4 miles wide and is marked with minor hills or ridges. Low bedrock hills, surrounded by alluvium, lie southwest of Wolf Point and Poplar. The general configuration of the buried valley floor was determined by drilling test holes along six lines across the valley. Logs of the test holes are shown graphically on the map.

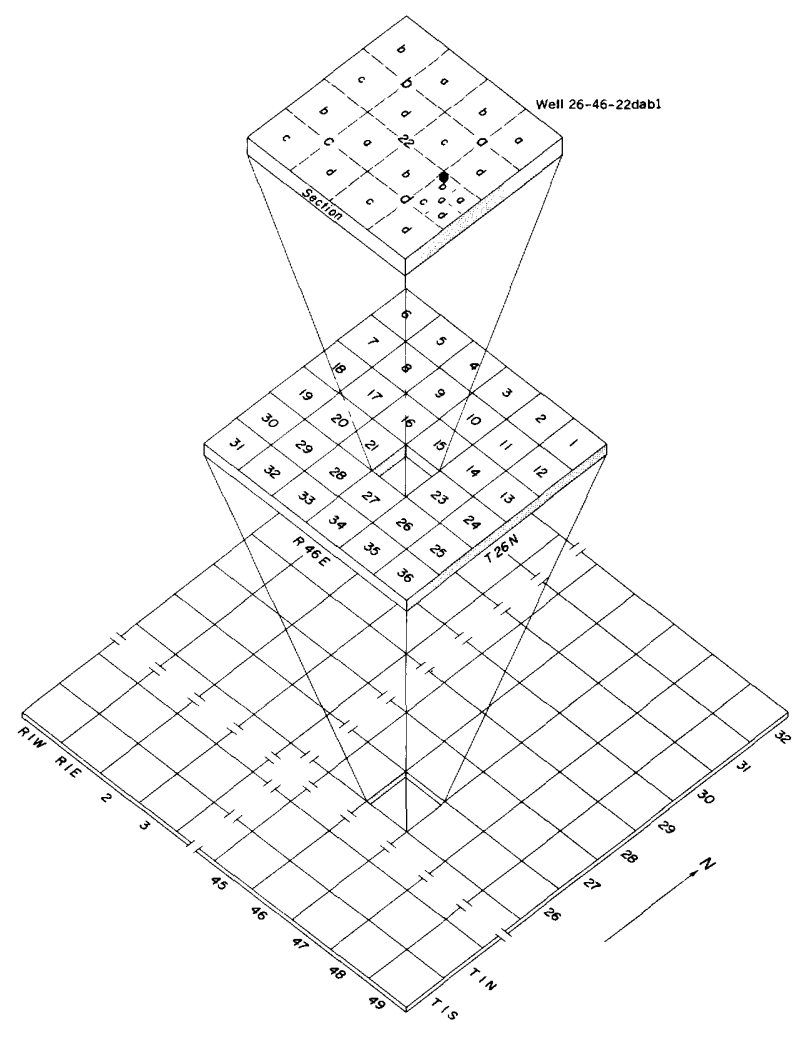

FIGURE 2-Diagram of well-numbering system.

The valley has been partly filled with extensive deposits of coarse- to fine-grained unconsolidated sediment. The sediment is a poorly stratified mixture of glacial outwash, stream deposits, and slope wash. Swenson (1955, p. 40-44) subdivided the sediment into several units that are shown on his geologic map, a part of which is used for this report. For convenience, the unconsolidated sediment is termed alluvium in this report because the colluvial slope wash and the glacial outwash are minor components. The alluvium has accumulated to a depth exceeding 100 feet in places and has masked most of the irregularities of the floor of the buried valley.

Surficial material consists of clay and silt at most locations. Water-bearing beds of sand, sandy clay, or gravelly sand were found in all test holes, but their depths below land surface were not uniform. Gravel forms the basal part of the alluvium in most of the valley and commonly is overlain by sand strata that contain some gravel. Jensen and Varnes $(1964$, p. 38) surmised that the basal gravel is glacial outwash.

\section{HYDROLOGY}

\section{Occurrence of ground water}

The size, shape, and distribution of the many open spaces in rocks determine to a great extent the oc- currence of ground water. Very little ground water is available from the Bearpaw Shale that bounds the Missouri River valley in the western part of the study area, but some is available from the Fox Hills Sandstone, Hell Creek Formation, and Fort Union Formation where they form the valley walls and floor in the eastern part of the area. Ground water that is readily available to wells occurs in sand and gravel strata in the alluvium. Water in the upper strata of the alluvium may be under either artesian (confined) or watertable (unconfined) conditions; water in the basal gravel normally is under artesian conditions.

\section{Recharge, movement, and discharge}

Ground water is a renewable resource, therefore, processes by which ground-water recharge, movement, and discharge occur affect the ground-water supply of the area. The upper sand aquifers in the alluvium are recharged principally from precipitation on the alluvium, applied irrigation water, runoff from the bordering uplands and hillsides, interformational leak age from the underlying gravel, and intermittent bank storage of streamflow.

Recharge to the gravel at the base of the alluvium probably is by leakage from the overlying sand and (or) from the underlying bedrock. Most of the runoff that comes into the valley from the adjacent uplands and hillsides recharges the overlying sand and does not reach the river as surface flow. Runoff that recharges the sand raises the altitude of the water table. When the water table in the sand is raised to a higher altitude than the piezometric surface of the water in the underlying gravel, leakage to the gravel is possible.

Interformational leakage from the underlying bedrock to the basal gravel of the alluvium probably is negligible west of Brockton where the bedrock is the Bearpaw Shale. East of Brockton, the alluvium is bounded by the Fox Hills Sandstone, Hell Creek Formation, and Fort Union Formation, all of which may contribute ground water to the gravel if the artesian pressure in the formation is greater than that in the gravel.

The position of the water table or piezometric surface along the lines of test holes drilled in 1963 is shown on the cross sections in figure 2 as of the time of drilling. The lines of test holes are approximately north-south lines and are essentially perpendicular to the river, therefore the slope shown represents but one component of the slope of the ground-water surface. During most of the year, ground water in the alluvium is moving in a direction that is downstream and toward the Missouri River. When the river level is higher than the level of the water table in the adjacent strata, movement of water is away from the river. River water that enters and leaves the alluvium in this way is termed bank storage.

Ground water is discharged from the alluvium principally by effluent seepage and evaportranspiration; minor quantities are discharged from wells. Effluent seepage occurs through much of each year and the Missouri River therefore is one of the main recipients of discharge for ground water. The water table is within a few feet of the land surface in large areas during most of the year and is at land surface for at least part of the year in many swampy areas. Evaporation from the water surfaces and from the soil and transpiration by vegetation effectively discharge large quantities of ground water.

Withdrawal of ground water for irrigation in T. 27 N., Rs. 47 and 48 E. has becomesignificant; however, 
no marked depletion of the ground-water supply has been noted by the irrigators. Other irrigation wells are located at widely dispersed sites in the area of investigation. The towns of Wolf Point, Poplar, and Brockton obtain their water supplies from wells, and the town of Culbertson has a well that is used as an emergency water supply. Several hundred wells in the area are used for domestic and stock-water supplies. The irrigation and municipal wells discharge water mainly from the basal gravel of the alluvium; the stock and domestic wells discharge water mainly from the upper sandy strata.

Most wells that yield more than 2 cubic feet per second penetrate at least 15 feet of saturated gravel. The thickest layers of gravel, in general, occupy the deeper parts of the buried valley. On the map, areas are shown where data from test holes and irrigation wells indicate that a yield of 2 cubic feet per second or more can be expected. Other areas where such yields are possible undoubtedly lie upstream and downstream beyond the boundaries indicated; however, the only reliable method of finding them is to drill test holes.

No wells have been constructed to obtain water for irrigation from the sandy strata in the alluvium. Such wells probably would not yield 2 cubic feet per second but would furnish lesser quantities.

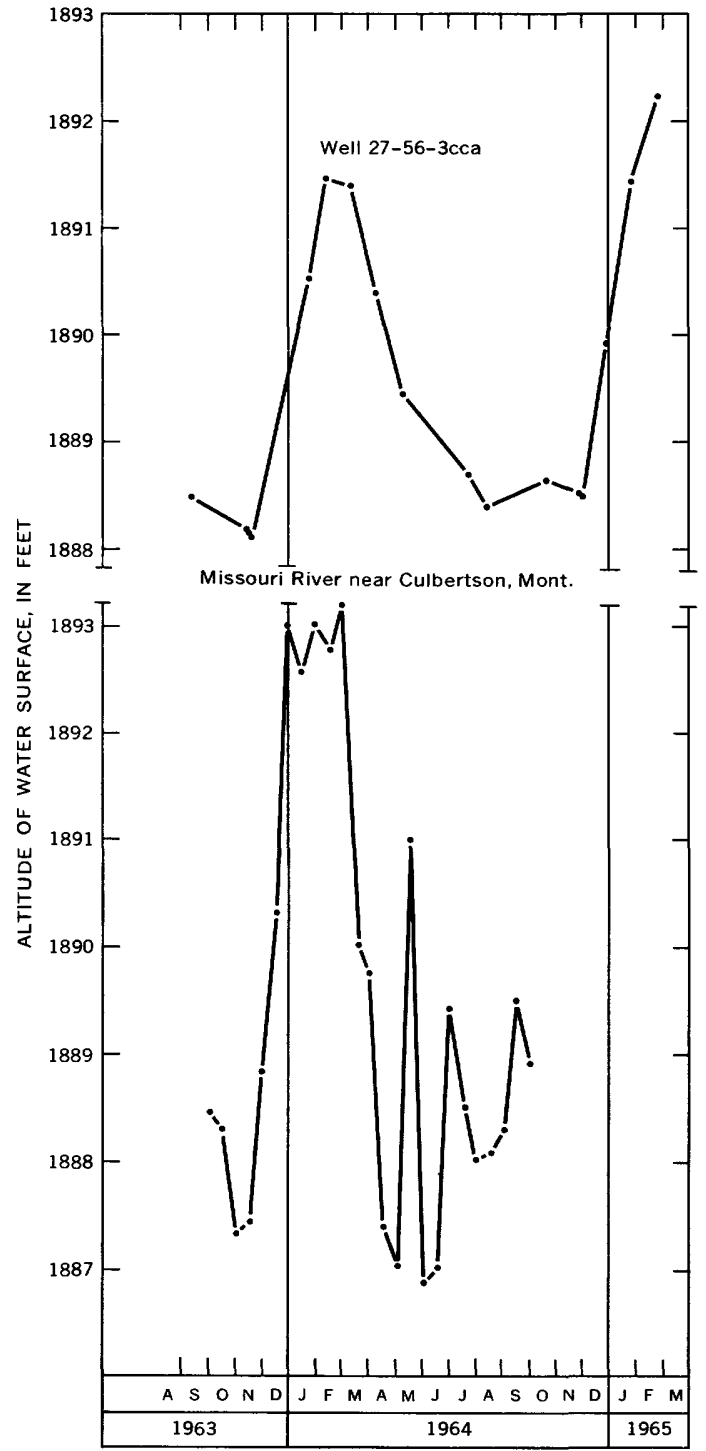

Fluctuations of water level

The water level in a well at any given time is the result of the relationships between recharge, movement, and discharge of ground water. The fluctuations of water levels in three observation wells and the stage of the Missouri River near Culbertson are shown by hydrographs in figure 3 . The water level in each well responds to a specific set of conditions. Well 28-57$28 d d$ is affected principally by precipitation and ground-water movement. Rises of the water level in this well are probably caused by precipitation. There is an apparent time lag between precipitation and the time of maximum water level. Well 27-46-26ddc is in an irrigated area and receives recharge from applied irrigation water during the growing season. During the winter months the ground generally is frozen and recharge from the scanty precipitation is negligible; consequently the water level in the well declines until the spring thaws begin. Well 27-56-3cca is near the Missouri River. The river is maintained at a relatively high stage during the winter, as water from Fort Peck Reservoir is released to generate electricity and replenish downstream reservoirs. During the summer months, water releases from Fort Peck are reduced, and the downstream river level is thereby lowered. The hydrograph of the Mis souri River at Culbertson shows the effects of the controlled releases

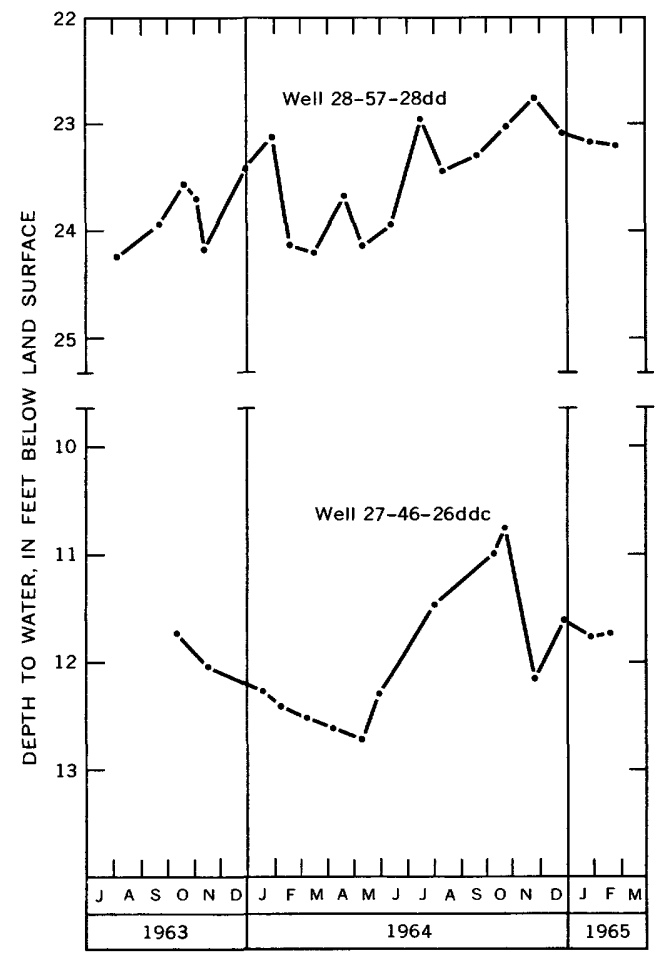

FIGURE 3.-Hydrographs of observation wells and of Missouri River near Culbertson. 
at Fort Peck dam. The sustained peak and low flows are reflected by the water level in well 27-56-3cca.

\section{Aquifer tests}

Tests of the basal gravel aquifer were made at selected wells to provide a basis for determining the coefficient of transmissibility of the aquifer, yield of irrigation wells, and the approximate range of specific capacity of wells. One test was made partly to explore the possibility of inducing recharge to the gravel from the Missouri River. A summary of the results of the aquifer tests is given in Table 1.

The coefficient of transmissibility, $T$, is defined as the rate of flow of water, at the prevailing water temperature, in gallons per day, through a vertical strip of the aquifer 1 foot wide extending the full saturated height of the aquifer under a hydraulic gradient of 100 percent (Ferris and others, 1962, p. 72-73). The specific capacity of a well is the yield of the well in gallons per minute per foot of drawdown.

Aquifer tests used in this study were drawdown and recovery tests. A drawdown test is made by pumping a well at a constant rate and measuring the depth to water periodically in the pumped well and in observation wells that lie within the cone of depression produced by pumping. (See fig. 4.) A recovery test is

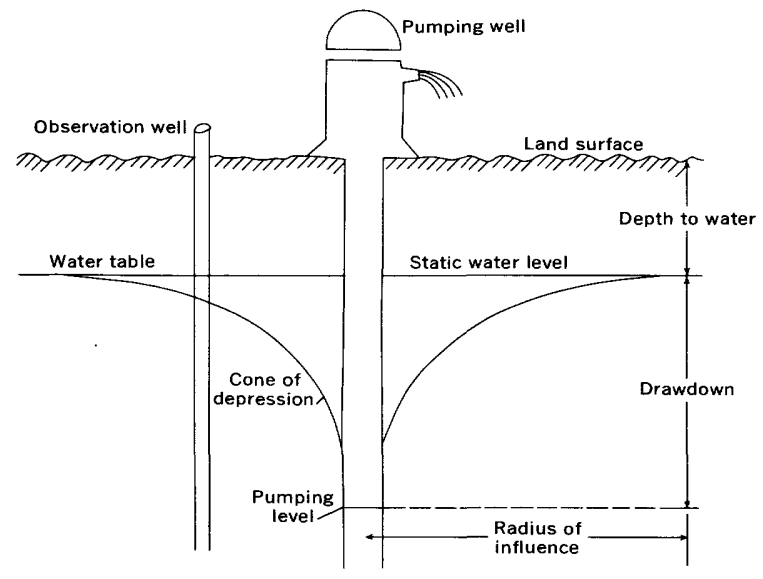

FIGURE 4.-Diagrammatic section of a well that is being pumped, showing its cone of depression, drawdown, and radius of influence.

made after the pump is stopped by measuring the depth to water periodically until there is no longer a cone of depression. Detailed analyses of the theories of ground-water movement and their application have been presented by Ferris and others (1962) and Bentall (1963a, 1963b).

As a means of checking the results, both drawdown and recovery tests were made on most of the wells, and the transmissibilities were also computed from the specific capacities. Because the tests were not made under ideal conditions, the differences between the " $T$ " values as obtained by the several methods are large for some wells. Nevertheless, the data are significant when used with the knowledge that any given value is only an approximation.

The aquifer test of well 27-55-laad3 was designed in part to study the possibility of inducing recharge to the gravel aquifer from the Missouri River. The gravel aquifer at this site is overlain by about 85 feet of saturated sand. Figure 5 shows the arrangement of the pumped well and three pairs of observation wells in relation to the river. In each pair of observation
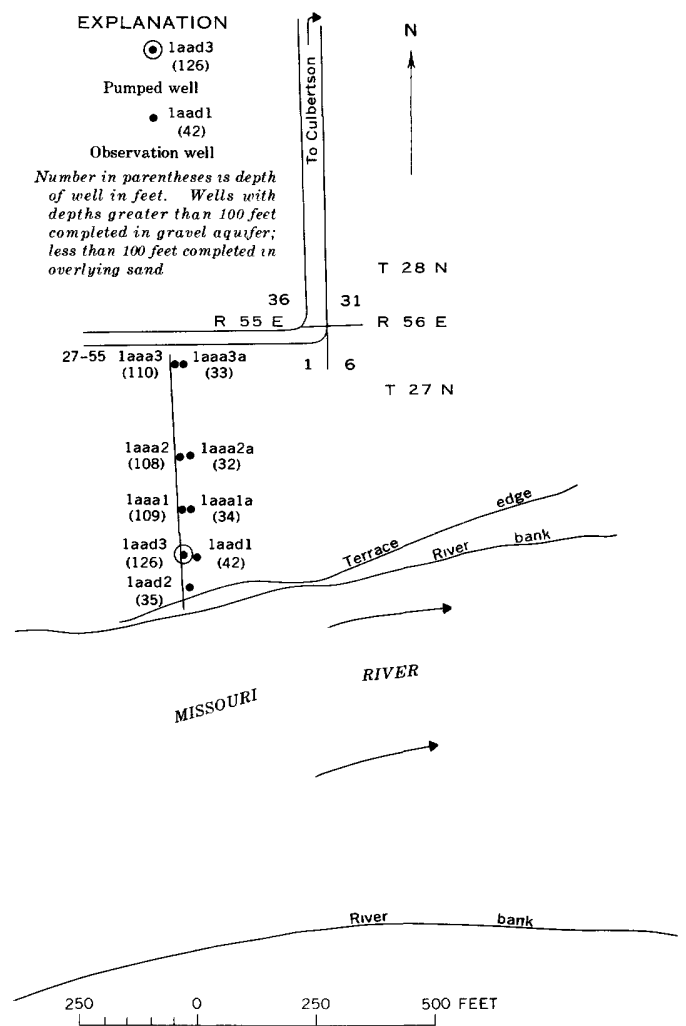

\llcorner

FIGURE 5.-Detail map of aquifer test site, well 27-55-1aad 3.

wells, one well was completed in the gravel aquifer and one was completed in the overlying sand. Two additional observation wells were completed in the sand at locations shown in figure 5.

During the pumping test the drawdown in the observation wells completed in the gravel was accompanied by concurrent but smaller drawdown in the wells completed in the sand. The leakage from the sand to the gravel tended to stabilize the cone of depression in the piezometric surface of the gravel aquifer and stop its growth. The recovery of the piezometric surface of the gravel aquifer after the pump was shut off was accompanied by a concurrent rise in the water table of the sand. A drawdown test in which there is leakage to the pumped aquifer from adjacent beds is known as a leaky aquifer test. From the leaky aquifer test data, the coefficient of vertical permeability of the adjacent beds may be computed.

The coefficient of vertical permeability is defined as the rate of flow of water in gallons per day through a horizontal cross-sectional area of 1 square foot under a hydraulic gradient of 100 percent. The coefficient of vertical permeability of the sand was computed to be about 5 gallons per day per square foot.

The pumped well, 27-55-laad3, was about 125 feet from the river bank and movement of water from the river to the well would be expected if the well and river were in hydraulic connection. The small drawdown in well 27-55-laad2, which lies between the pumped well and the river, indicated that the river was recharging the sand, which in turn was recharging the gravel. (See fig. 5.) The river water has a lower concentration of dissolved solids than does the ground water, but no significant changes in the chemical quality of the pumped water were noted during the 48hour test. Had the well been pumpedlonger it is pro- 
bable that an improvement in the quality of the pumped water would have occurred.

\section{Chemical quality of the ground water}

The chemical quality of water is important to irrigation farming in the study area. The amount and type of dissolved constituents in irrigation water are important in determining its suitability for use; however, climate, soil types, drainage, kinds of crops, and water-management practices also must be considered. Special management practices of irrigation with ground water may be required because of undersirable chemical characteristics of the water. These characteristics are closely related to the physical and chemical properties of the materials in contact with the water and to the length of contact time. Analyses of groundwater samples collected from the alluvium are presented in table 2 and are shown graphic ally on the map. Analyses of surface water are presented for comparison in table 3 .

\section{Suitability of water for irrigation use}

The chemical characteristics most important in evaluation of water for irrigation use are (1) total concentration of dissolved sclids, (2) concentrations of sodium and the relative proportion of sodium to other cations, (3) concentrations of boron and other elements that may be toxic, and (4) under some conditions, the concentrations of bicarbonate and carbonate as related to the concentrations of calcium and magnesium.

Large concentrations of dissolved solids are objectionable not only because of their toxicity to plants but also because they affect the ability of plant roots to obtain water. Plants consume water from the soil solution, but most of the dissolved solids are rejected on the root surfaces of the plants. The rejected dissolved solids may accumulate in the root zone in such high concentrations that normal water consumption by plants will be hindered. Leaching the soil will flush most of the accumulated salts from the root zone if soil drainage is adequate and the water table lies below the root zone.

Large concentrations of sodium (or large concentrations of sodium in proportion to the concentrations of calcium and magnesium) in the applied water may affect the structure of certain soils that have a high cation-exchange capacity. Sodium may replace the calcium and magnesium adsorbed on the soil particles and cause the soil to become compacted, which will result in restricted drainage. Conversely, calcium and magnesium from water that contains them in large concentrations may replace sodium adsorbed on the soil particles and cause the soil to become flocculated. Flocculation will improve drainage and tilth of the soil.

A classification diagram for irrigation water (U.S. Salinity Laboratory Staff, 1954), is shown in figure 6 . The salinity hazard of irrigation water is designated by the specific conductance, the sodium hazard is designated by sodium-adsorption-ratio (SAR). Specific conductance is a measurement of the ability of water to conduct an electrical current and is a rough measure of the concentration of dissolved solids in the water. The SAR and specific conductance values for the samples are listed in table 2 and are plotted on the classification diagram, figure 6 . The classification diagram may be used as a guide in appraisal of the quality of irrigation water only if water management, soil texture, infiltration rate, drainage and other factors are average. Interpretation of the classes is as follows:
Low-salinity water (C1) can be used for irrigation on most soils with little likelihood that soil salinity will develop.

Medium-salinity water (C2) can be used under moderate drainage conditions. Generally, plants with moderate salt tolerance can be grown without special practices for salinity control.

High-salinity water (C3) cannot be used on soils with restricted drainage. Even with adequate drainage, special management for salinity control may be required and plants with good salt tolerance should be selected. Over 50 percent of the samples analyzed are classified as high salinity water; the samples included eight from irrigation wells.

Very high salinity water (C4) is not suitable for irrigation under ordinary conditions but may be used occasionally under very special circumstances. The soils must be permeable, drainage must be adequate, irrigation water must be applied in excess to provide considerable leaching, and very salt-tolerant crops should be selected. Over 30 percent of the samples analyzed are classifiedas very high salinity water. Samples from six irrigation wells were in class C4.

Low-sodium water (S1) can be used for irrigation on almost all soils with little danger of development of harmful levels of exchangeable sodium.

Medium-sodium water (S2) will present an appreciable sodium hazard in fine textured soils having high cation-exchange-capacity, especially under poor drainage conditions. This water may be used on coarse-textured or organic soils with high permeability. Nearly half of the samples analyzed are classified as medium-sodium water.

High-sodium water (S3) produces harmful levels of exchangeable sodium in most soils and will require good drainage, high leaching, and addition of organic matter.

Very high sodium water (S4) is generally unsatisfactory for irrigation except at low or perhaps medium salinity where the solution of calcium from the soil or use of gypsum or other amendments may make the use of the water feasible.

Boron is essential in very small quantities for normal growth of all plants; however, it is toxic in larger concentrations. The concentration of boron in 50 samples of ground water ranged from 0.06 to $0.68 \mathrm{ppm}$ (parts per million) with a median of $0.23 \mathrm{ppm}$. Wheat, alfalfa, and safflower, which are the principal crops grown in northeastern Montana, are not known to be affected adversely by such concentrations of boron.

Sodium bicarbonate and carbonate raise the $\mathrm{pH}$ of the soil and may cause "black alkali" deposits. Concentrations of sodium bicarbonate and carbonate in the ground water locally are high enough to cause adverse soil conditions. According to Eaton (1950, p. 123-133), water that contains a concentration of more than 2.5 epm (equivalents per million) residual sodium carbonate is unsuitable for irrigation. Residual sodium carbonate determinations were made for 69 of the samples listed in table 2 of these 69 samples, over 43 percent contained more than 2.5 epm residual sodium carbonate.

Water from the alluvium ranges widely in salinity or dissolved solids concentration and, for most local areas, is characterized by a predominance of sodium and sulfate. The sulfate concentration is directly proportional to the total dissolved solids concentration of the more saline waters, as indicated in figure 7. Concentrations of the principal cations are not directly proportional to the concentration of total dissolved solids, owing mainly to cation exchange by the soils. 


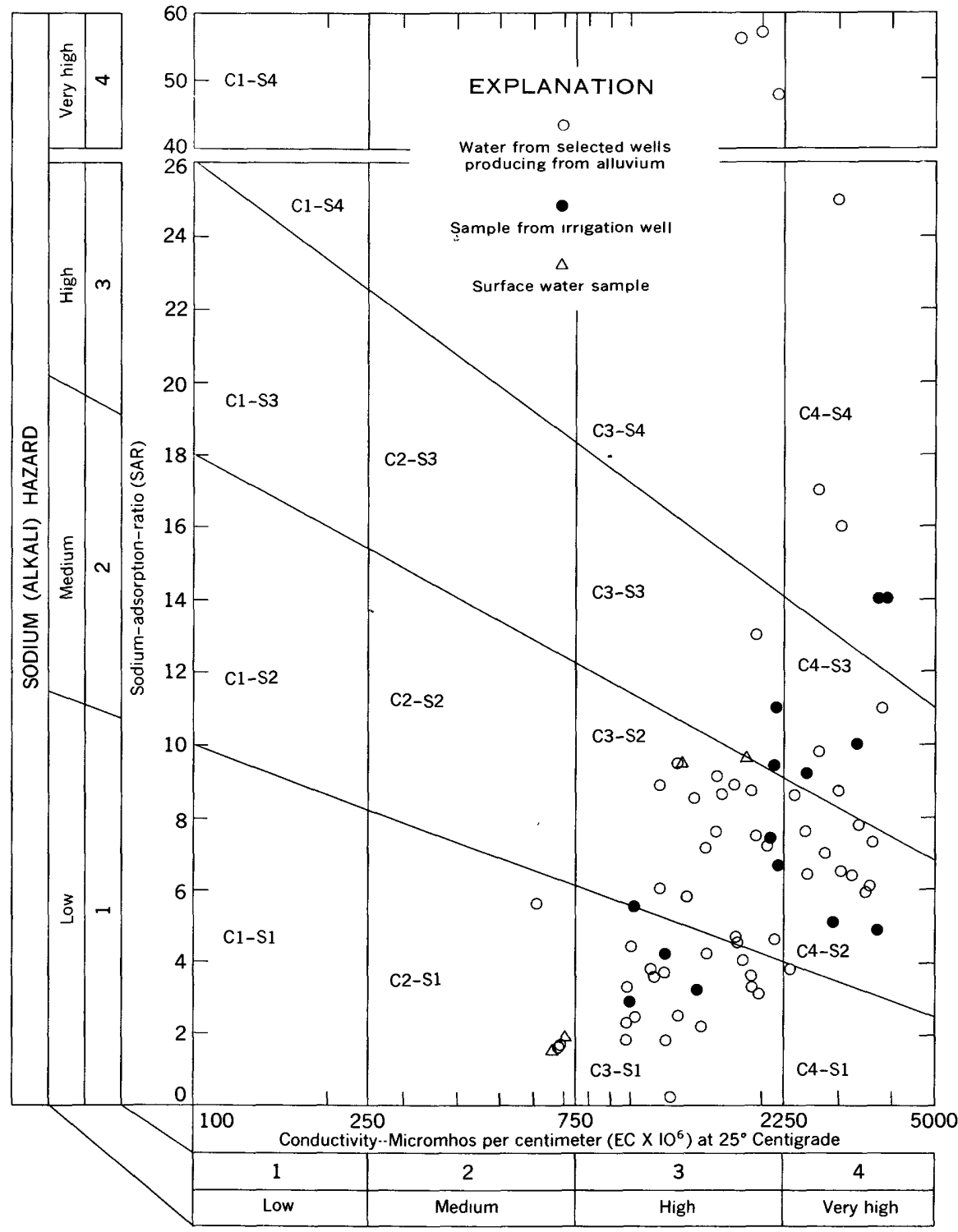

FIGURE 6.-Classification of irrigation water.

Differences in type of bedrock immediately underlying the alluvium may affect the quality of water in the alluvium where leakage from bedrock aquifers occurs. The chemical composition of water from the alluvium near Brockton closely resembles that of water from the bedrock. See table 2 and Swenson (1955, p. 48-49).

Analyses of water collected from several adjacent wells, from test holes of different depths, and from different depths in individual test holes indicate slight differences in chemical characteristics with depth. Deeper wells tend to have higher concentrations of dissolved solids and higher concentrations of sodium in relation to other cations.

Seepage from Big Muddy Creek and the Poplar River undoubtedly has a favorable affect on the quality of water in the alluvium locally. Seepage from irrigation canals and ditches in the Frazer-Oswego area probably contributes favorably to the ground-water quality. Two of the three samples that are classified as C2-Si on figure 6 are from shallow wells in the Frazer-Wolf Point irrigation project.

Chemical characteristics of water are essentially unchanged with respect to time, as shown by analyses of samples collected in 1947 and during this study. Slight seasonal variations in chemical characteristics may occur, mainly as a result of seepage from streams and applied irrigation water.

\section{Suitability of water for domestic use}

Water suitable for irrigation may not be satisfactory for domestic use because the chemical-quality requirements are not the same.Standards established by the U.S. Public Health Service (1962) for drinking water supplied on interstate carriers are useful as criteria of water quality for domestic use. The maximum concentrations permitted by the U. S. Public Health Service standards for some of the common constituents are compared in the following table with the concentrations found in ground water in the study area. 


\begin{tabular}{|c|c|c|c|c|c|}
\hline Constituent & \begin{tabular}{|c|} 
Maximum \\
permitted \\
concentra- \\
tion, in parts \\
per million
\end{tabular} & $\mid \begin{array}{c}\text { Sample concen- } \\
\text { tration range, } \\
\text { in parts per } \\
\text { million }\end{array}$ & $\begin{array}{c}\text { Median sample } \\
\text { concentration } \\
\text { in parts per } \\
\text { million }\end{array}$ & $\begin{array}{l}\text { Percentage } \\
\text { of samples } \\
\text { exceeding } \\
\text { maximum } \\
\text { permitted } \\
\text { concentration }\end{array}$ & $\begin{array}{c}\text { Number } \\
\text { of } \\
\text { samples }\end{array}$ \\
\hline Fluoride_.... & a 1.5 & $0.0-$ & 0.7 & 3 & 59 \\
\hline Iron_. & .3 & $.0-$ & 2.1 & 67 & 64 \\
\hline Manganese_- & .05 & $.02-\quad 2.8$ & .53 & 83 & 18 \\
\hline Nitrate _. - & 45 & $.0-208$ & 1.7 & 5 & 59 \\
\hline Chloride_... & 250 & $2.0-\quad 137$ & 13 & 0 & 59 \\
\hline Sulfate & 250 & $6.0-1,750$ & 503 & 75 & 73 \\
\hline Dissolved sol & 500 & $410-3,350$ & 1,350 & 96 & 73 \\
\hline
\end{tabular}

${ }^{a}$ Varies for different parts of the country.

Excessive concentrations of sulfate, dissolved solids, and nitrate are likely to produce adverse physiological effects, whereas excessive concentrations of other constituents generally are harmless but produce undesirable tastes, colors, or odors. Durum (Swenson, 1955, p. 60) noted that "***in areas where water supplies of a low mineral content are difficult to obtain, the residents have become accustomed to drinking water of relatively high mineral content*** the presentation of any standards, ratings, or limits for defining the general domestic utility of the water is useful for comparison only."

\section{Summary and conclusions}

The alluvium in the Missouri River valley attains a maximum thickness of about 140 feet and is composed of clay, silt, sand, and gravel. A basal gravel bed of variable thickness is present under most of the valley. The thickest gravel lies in the deeper parts of the buried valley and can be located only by test drilling. Most irrigation wells that obtain 2 cubic feet per second of water penetrate at least 15 feet of the basal gravel. Lesser quantities can be obtained where the gravel is thinner. Areas where data from test holes and irrigation wells indicate a thickness of 15 feet or more of gravel are shown on the map.

The sandy strata above the basal gravel are water bearing, but their potential yield to wells is not known. Water from the sandy strata will descend into the gravel to replace that pumped from the gravel.

Ground water being used for irrigation is classified as $\mathrm{C} 3$ or $\mathrm{C} 4$ water. High salinity and excessive concentration of sodium and bicarbonate make accumu-

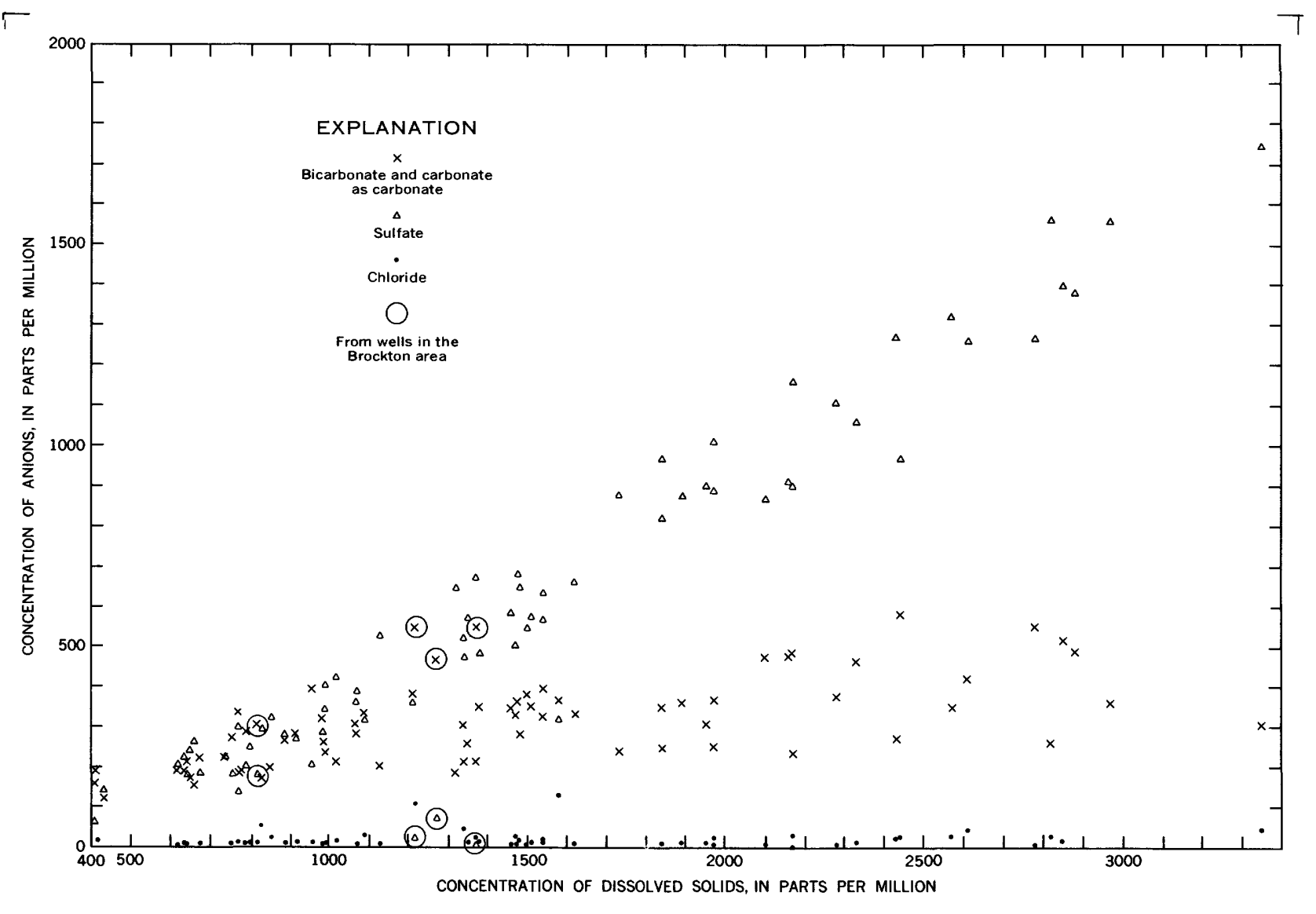

FIGURE 7.-Relationship of dissolved solids and principal anions. 
lation of salts in the soil a hazard unless drainage is adequate to permit considerable leaching and careful management of water is practiced. The quality of water in areas of high well yield could be improved by locating the wells as close to the Missouri River as possible where recharge from the river by water of better quality would act as a dilutant.

Concentrations of iron, sulfate, and total dissolved solids in the ground water are sufficiently high to affect adversely the suitability of the water as a domestic supply.

\section{REFERENCES CITED}

Bentall, Ray, 1963a, Methods of determining permeability, transmissibility and drawdown: U.S. Geol. Survey Water-Supply Paper 1536-I, p. 243341.

$1963 \mathrm{~b}$, Shortcuts and special problems in aquifer tests: U.S. Geol. Survey Water-Supply Paper 1545-C, $117 \mathrm{p}$.
Colton, Roger B., 1955, Geology of the Wolf Point quadrangle, Montana: U.S. Geol. Survey Quad. Map GQ-67.

Eaton, F. M., 1950, Significance of carbonates in irrigation waters: Soil Sci., V. 69, no. 2, p. 123-133.

Ferris, J. G. and others, 1962, Theory of aquifer tests: U.S. Geol. Survey Water-Supply Paper 1536-E, p. 69-174.

Jensen, F. S., and Varnes, H. D., 1964, Geology of the Fort Peck area, Garfield, McCone and Valley Counties, Montana: U.S. Geol. Survey Prof. Paper 414-F, 49 p.

Swenson, F. A., 1955: Geology and ground-water resources of the Missouri River valley in northeastern Montana: U.S. Geol.Survey Water-Supply Paper 1263, $128 \mathrm{p}$.

U.S. Public Health Service, 1962, Drinking water standards: U.S. Public Health Service publication $956,61 \mathrm{p}$.

U.S. Salinity Laboratory Staff, 1954, Diagnosis and improvement of saline and alkali soils: U.S. Dept. Agriculture, Agriculture Handbook no. 60, 160 p. 


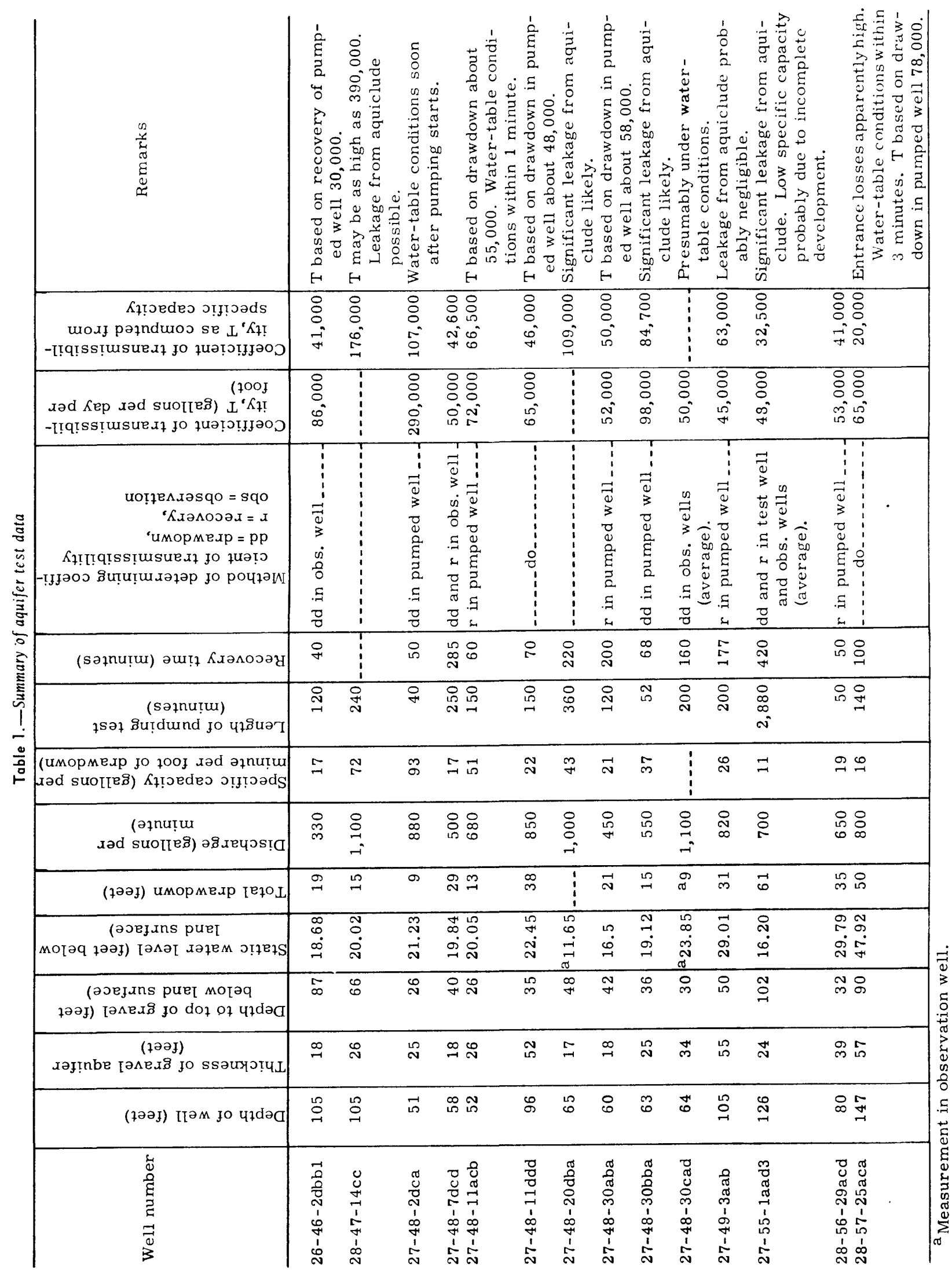


Table 2.-Chemical analyses of uater from

[Results in parts per mil

\begin{tabular}{|c|c|c|c|c|c|c|c|c|c|c|c|c|c|}
\hline Well number & $\begin{array}{l}\text { Depth } \\
\text { (feet) }\end{array}$ & $\begin{array}{l}\text { Date of } \\
\text { collection }\end{array}$ & $\begin{array}{c}\text { Tem- } \\
\text { pera- } \\
\text { ture } \\
\left({ }^{\circ} \mathrm{F}\right)\end{array}$ & $\begin{array}{l}\text { Silica } \\
\left(\mathrm{SiO}_{2}\right)\end{array}$ & $\begin{array}{l}\text { Iron } \\
(\mathrm{Fe})\end{array}$ & $\begin{array}{c}\text { Man- } \\
\text { ga- } \\
\text { nese } \\
(\mathrm{Mn})\end{array}$ & $\begin{array}{c}\text { Cal- } \\
\text { cium } \\
(\mathrm{Ca})\end{array}$ & $\begin{array}{c}\text { Mag }- \\
\text { ne- } \\
\text { sium } \\
\text { (Mg) }\end{array}$ & $\begin{array}{c}\text { So- } \\
\text { dium } \\
(\mathrm{Na})\end{array}$ & $\begin{array}{c}\text { Po- } \\
\text { tas- } \\
\text { sium } \\
(\mathrm{K})\end{array}$ & $\begin{array}{l}\text { Bicar- } \\
\text { bonate } \\
\left(\mathrm{HCO}_{3}\right)\end{array}$ & $\left|\begin{array}{c}\mathrm{Car}- \\
\text { bon- } \\
\text { ate } \\
\left(\mathrm{C}^{\prime} \mathrm{O}_{3}\right)\end{array}\right|$ & $\begin{array}{l}\text { Sul- } \\
\text { fate } \\
\left(\mathrm{SO}_{4}\right)\end{array}$ \\
\hline $26-44-10 b c c$ & 18 & Sept. 5, 1963 & & 14 & 3.5 & 2.1 & 76 & 28 & 145 & 3.9 & 377 & 0 & 296 \\
\hline 26-45- 3aаa & 47.8 & Sept. 6, 1963 & 61 & 19 & 7.0 & 2.8 & 179 & 59 & 422 & 7.4 & 482 & 0 & 1,160 \\
\hline $26-45-7 \mathrm{ada}$ & 63 & Sept. 9,1963 & 56 & $\ldots$ & 3.1 & $\ldots$ & $\ldots$ & $\ldots$ & 56 & $-\ldots$ & 256 & 0 & 140 \\
\hline $26-46-2 \mathrm{dbb} 1$ & 106 & Nov. 6,1963 & $\ldots$ & 20 & 9.5 & 1.2 & 132 & 46 & 360 & 7.0 & 685 & 0 & 66.7 \\
\hline $26-46-2 d c d$ & 105 & Oct. 22,1963 & 51 & & 1.6 & - & $\ldots$ & $\ldots$ & 402 & $\ldots-\ldots$ & 627 & 0 & 522 \\
\hline $26-58-1 \mathrm{bad}$ & 90 & Apr. 15,1964 & 48 & 20 & .97 & & 256 & 102 & 544 & 16 & 1,060 & 0 & $1,+00$ \\
\hline $27-43-31 b b b$ & 30 & Oct. 9,1947 & 49 & 16 & .30 & --- & 161 & 61 & 193 & 16 & 441 & 0 & 672 \\
\hline $27-44-32 d c d$ & 28 & Sept. 5, 1963 & 58 & $\ldots$ & .35 & $\ldots$ & $\ldots \ldots$ & $\ldots$ & 228 & $\ldots$ & 382 & 0 & 650 \\
\hline $27-45-33 c d d$ & 21 & Oct. 9,1947 & 46 & 12 & 2.1 & & 14 & 45 & 588 & 18 & 524 & 0 & 1,010 \\
\hline $27-46-26 a b a$ & 42 & Nov. 17, 1963 & 47 & 17 & $\cdots$ & & 22 & 6.1 & 115 & 2.7 & 322 & 0 & 61 \\
\hline $27-46-26 \mathrm{ddc}$ & 80 & Oct. 8,1963 & $\ldots$ & 17 & 4.4 & 1.5 & 108 & 45 & 354 & 5.2 & 718 & 0 & 572 \\
\hline $27-46-35 d c d$ & 73 & Oct. 22,1963 & 49 & 18 & 3.5 & .53 & 103 & 34 & 342 & 5.4 & 720 & 0 & 487 \\
\hline $27-47-14 c c$ & 106 & Oct. 18,1963 & $\ldots$ & 20 & 5.1 & .53 & 85 & 32 & 402 & 5.4 & 659 & 0 & 635 \\
\hline $27-47-15 a c$ & 93 & Oct. 10,1947 & 48 & 16 & 2.8 & $\ldots$ & 106 & 36 & 220 & 8.0 & 412 & 0 & 529 \\
\hline $27-47-15 \mathrm{cb} 2$ & 100.4 & Oct. 15,1947 & 51 & 25 & 1.5 & $\ldots$ & 74 & 33 & 359 & 2.4 & 532 & 0 & 572 \\
\hline $27-47-15 d c c$ & 110 & Oct. 16,1964 & 46 & 18 & 5.1 & & 56 & 26 & 310 & 5.8 & 684 & 0 & 314 \\
\hline $27-47-21 \mathrm{aad}$ & 100 & Oct. 16,1964 & 46 & 17 & 5.8 & & 60 & 30 & 288 & 5.3 & 623 & 0 & 360 \\
\hline $27-47-22 b b d$ & 94 & Oct. 16,1964 & 47 & 18 & 3.1 & - & 49 & 24 & 310 & 5.1 & 576 & 0 & 390 \\
\hline $27-47-24 c c c$ & 54 & July 23,1964 & 49 & 19 & 8.8 & & 100 & 55 & 162 & 7.1 & 486 & 0 & 402 \\
\hline $27-47-25 \mathrm{dd} 1$ & 20 & Oct. 10,1947 & 47 & 16 & .10 & & 174 & 56 & 240 & 3.2 & 688 & 0 & 503 \\
\hline $27-47-25$ dd 1 & 20 & Sept. 5, 1963 & 61 & 12 & .04 & 1.2 & 124 & 63 & 200 & 36 & 442 & 0 & 473 \\
\hline $27-48-2 d c a$ & 51 & Oct. 15,1964 & 45 & 18 & 3.5 & & 113 & 62 & 726 & 7.6 & 546 & 0 & 1,560 \\
\hline $27-48-7 b d b$ & 48 & Sept. 7, 1963 & 46 & $\ldots$ & 3.3 & $\ldots$ & $\ldots$ & $\ldots$ & 750 &.- & 746 & 0 & 1,560 \\
\hline $27-48-7 \mathrm{dcd}$ & 60 & Sept. 7, 1963 & 45 & 18 & 2.8 & 1.4 & 95 & 51 & 447 & 5.7 & 722 & 0 & 815 \\
\hline $27-48-10 \mathrm{cb} 1$ & 35.6 & Oct. 10,1947 & 46 & 14 & 2.3 & $-\cdots$ & 100 & 40 & 197 & 11 & 662 & 0 & 288 \\
\hline $27-48-11 \mathrm{acb}$ & 52 & Sept. 7, 1964 & 45 & 17 & 7.0 & & 156 & 71 & 603 & 7.2 & 716 & 0 & 1,320 \\
\hline $27-48-11 d d d$ & 96 & Sept. 8, 1964 & 46 & 18 & 5.3 & ---1 & 74 & 31 & 171 & 4.2 & 500 & 0 & 248 \\
\hline $27-48-20 \mathrm{dba}$ & 66 & Sept. 6, 1963 & $\ldots$ & 18 & 3.5 & .11 & 75 & 27 & 115 & 3.5 & 436 & 0 & 178 \\
\hline $27-48-30 a b a$ & 60 & July 23,1964 & 48 & 18 & 15 & & 211 & 118 & 376 & 7.8 & 555 & 0 & 1,270 \\
\hline $27-48-30 \mathrm{bba}$ & 63 & Oct. 14,1964 & $\ldots$ & 17 & 25 & & 362 & 152 & 436 & 15 & 630 & 0 & 1,750 \\
\hline $27-48-30 \mathrm{cad}$ & 64 & Aug. 29, 1964 & 47 & 20 & 4.3 & & 80 & 56 & 358 & 5.0 & 704 & 0 & 582 \\
\hline $27-49-1$ ada & 97 & Oct. 10,1963 & 48 & $\ldots \ldots$ & $\ldots$. & - & $\ldots-n$ & $\ldots$ & 148 & $\ldots-$ & 311 & 0 & 261 \\
\hline $27-49-1$ ada & 97 & Oct. 10,1963 & 47 & $\ldots-.--$ & .69 & & $\ldots-$ & $\ldots$ & 95 & -- & 349 & 0 & 237 \\
\hline $27-49-1 \mathrm{dad}$ & 85 & Oct. 28,1963 & 47 & 16 & $\ldots$ & & 49 & 17 & 193 & 3.5 & 377 & 0 & 292 \\
\hline $27-49-3 a a b$ & 105 & Sept. 2, 1964 & 46 & 13 & .06 & & 70 & 35 & 224 & 4.2 & 430 & 0 & 424 \\
\hline $27-49-3 \mathrm{ca}$ & 60 & Oct. 14,1947 & 47 & 11 & .34 & & 58 & 25 & 255 & 10 & 534 & 0 & 345 \\
\hline $27-49-9 \mathrm{dbc}$ & 90 & Sept. 7, 1963 & $\ldots$ & $\ldots$ & 2.6 & & $\ldots$ & $\ldots$ & 342 & 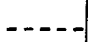 & 782 & 0 & 360 \\
\hline $27-49-12 a d d$ & 98 & Oct. 31,1963 & 47 & 16 & .00 & $\ldots$ & 85 & 42 & 82 & 2.4 & 380 & 0 & 226 \\
\hline $27-49-13$ aас & 86 & Nov. 5,1963 & 48 & 22 & 7.4 & .88 & 89 & 31 & 107 & 4.8 & 453 & 0 & 187 \\
\hline $27-50-12 \mathrm{ab} 1$ & 99 & Oct. 15,1964 & $\cdots$ & 18 & .02 & & 28 & 15 & 234 & 4.6 & 559 & 0 & 177 \\
\hline $27-50-12 a d d$ & 96 & Oct. 15,1964 & 51 & 18 & .05 & & 39 & 21 & 267 & 7.0 & 575 & 0 & 271 \\
\hline $27-50-13 b d d$ & 65 & Sept. 7, 1963 & 57 & 9.9 & .67 & .39 & 54 & 31 & 214 & 4.7 & 541 & 0 & 281 \\
\hline $27-51-14 b d c$ & 30 & Oct. 7,1964 & 48 & 17 & .02 & -- & 146 & 61 & 125 & 6.3 & 804 & 0 & 208 \\
\hline $27-51-18 b c$ & 73 & Oct. $\quad 7,1964$ & 48 & 19 & .07 & & 183 & 59 & 279 & 7.0 & 803 & 0 & 568 \\
\hline $27-51-21 b b a$ & 20 & Oct. 7,1964 & 54 & 16 & .01 & & 115 & 56 & 93 & 6.8 & 688 & 0 & 134 \\
\hline $27-51-29 a b b$ & 77 & Sept. 7, 1963 & 57 & 2.9 & .26 & .03 & 7.1 & 23 & 617 & 9.2 & 588 & 20 & 900 \\
\hline $27-52-17 b b$ & 75 & Sept. 9, 1963 & 53 & $\ldots$ & 2.2 & $\ldots$ & $\ldots-$ &.- & 150 & --- & 463 & 0 & 227 \\
\hline $27-53-6 b c d$ & 80 & Oct. 8,1964 & 48 & 19 & .08 & & 222 & 88 & 540 & 9.4 & 864 & 0 & 1,260 \\
\hline $27-55-1$ aaa 1 & 109 & Apr. 30,1964 & 48 & & --- & & & & & 3 & 976 & 0 & 912 \\
\hline $27-55-1$ aad2 & 36 & Apr. $30,1964 \mid$ & 49 & 17 & .30 & & 90 & 23 & 6521 & 4.4 & 976 & 0 & 870 \\
\hline
\end{tabular}


selected wells producing from the alluvium

lion except as indicated]

\begin{tabular}{|c|c|c|c|c|c|c|c|c|c|c|c|c|c|}
\hline \multirow{2}{*}{$\begin{array}{l}\text { Chlo- } \\
\text { ride } \\
\text { (Cl) }\end{array}$} & \multirow{2}{*}{$\begin{array}{c}\text { Fluo- } \\
\text { ride } \\
(\mathrm{F})\end{array}$} & \multirow{2}{*}{$\begin{array}{c}\mathrm{Ni}- \\
\text { trate } \\
\left(\mathrm{NO}_{3}\right)\end{array}$} & \multirow[b]{2}{*}{$\begin{array}{c}\text { Boron } \\
\text { (B) }\end{array}$} & \multicolumn{2}{|c|}{ Dissolved solids } & \multirow{2}{*}{$\begin{array}{c}\text { Hard- } \\
\text { ness } \\
\text { as } \\
\mathrm{CaCO}_{3}\end{array}$} & \multirow{2}{*}{$\begin{array}{c}\text { Noncar- } \\
\text { bonate } \\
\text { hard- } \\
\text { ness as } \\
\mathrm{CaCO}_{3}\end{array}$} & \multirow{2}{*}{$\begin{array}{c}\text { Per- } \\
\text { cent } \\
\text { so- } \\
\text { dium }\end{array}$} & \multirow{2}{*}{$\begin{array}{c}\text { Sodium- } \\
\text { adsorp- } \\
\text { tion } \\
\text { ratio } \\
\text { (SAR) }\end{array}$} & \multirow{2}{*}{$\begin{array}{c}\text { Specific } \\
\text { conduct- } \\
\text { ance } \\
\text { (micro- } \\
\text { mhos per } \\
\text { cm at } \\
\left.25^{\circ} \mathrm{C}\right)\end{array}$} & \multirow[b]{2}{*}{$\mathrm{pH}$} & \multirow{2}{*}{$\begin{array}{c}\text { Residual } \\
\text { sodium } \\
\text { carbon- } \\
\text { ate } \\
(\text { epm) }\end{array}$} & \multirow[b]{2}{*}{$\begin{array}{l}\text { Irri- } \\
\text { gation } \\
\text { class }\end{array}$} \\
\hline & & & & $\begin{array}{l}\mathrm{Ca1-} \\
\mathrm{cu}- \\
\text { lated }\end{array}$ & $\begin{array}{c}\text { Residue } \\
\text { on evap- } \\
\text { oration } \\
\text { at } 180^{\circ} \mathrm{C}\end{array}$ & & & & & & & & \\
\hline 13 & 0.5 & 0.1 & 0.23 & 767 & 773 & 304 & 0 & 51 & 3.6 & 1,150 & 7.9 & 0.10 & $\mathrm{C} 3-\mathrm{S} 1$ \\
\hline 33 & .4 & .7 & .19 & 2,130 & 2,170 & 689 & 294 & 57 & 7.0 & 2,800 & 8.0 & 0 & $\mathrm{C} 4-\mathrm{S} 2$ \\
\hline & & & $\ldots$ & & 432 & 244 & 34 & 33 & 1.6 & 686 & 7.6 & 0 & C2-S1 \\
\hline 13 & .7 & 7.2 & .29 & 1,590 & 1,620 & 519 & 0 & 59 & 6.7 & 2,190 & 7.0 & .85 & C3-S2 \\
\hline$-\ldots$ & $-\cdots$ &.- & $\ldots$ & 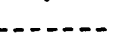 & 1,340 & 173 & 0 & 83 & 13 & 1,960 & 7.8 & 6.82 & C3-S3 \\
\hline 24 & .7 & 12 &.-- & 2,900 & 2,850 & 1,060 & 191 & 52 & 7.3 & 3,610 & 7.8 & 0 & $\mathrm{C} 4-\mathrm{S} 2$ \\
\hline 25 & .5 & 6.0 & .25 & $\ldots$ & 1,370 & 653 & 291 & 38 & 3.3 & 1,900 & 7.6 & $-\infty$ & $\mathrm{C} 3-\mathrm{S} 1$ \\
\hline$-\ldots$ & $\ldots$ &..- & $\ldots$ & . - - & 1,320 & 487 & 174 & 50 & 4.5 & 1,780 & 7.7 & 0 & C3-S2 \\
\hline 26 & .8 & 2.2 & .50 & 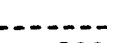 & 1,970 & 220 & 0 & 84 & 17 & 2,670 & 7.3 & 4.19 & $\mathrm{C} 4-\mathrm{S} 4$ \\
\hline 4.0 & 1.4 & .3 & .31 & 388 & 412 & 80 & 0 & 75 & 5.6 & 614 & 8.0 & 3.68 & $\mathrm{C} 2-\mathrm{S} 1$ \\
\hline 14 & .5 & 3.8 & .19 & 1,480 & 1,510 & 455 & 0 & 63 & 7.2 & 2,090 & 7.8 & 2.67 & C3-S2 \\
\hline 16 & .7 & 1.3 & .29 & 1,370 & 1,380 & 396 & 0 & 65 & 7.5 & 1,950 & 7.9 & 3.88 & C3-S2 \\
\hline 12 & .8 & 1.3 & .43 & 1,520 & 1,540 & 344 & 0 & 71 & 9.4 & 2,150 & 7.7 & 3.92 & C3-S3 \\
\hline 11 & .2 & 2.5 & .14 & $\ldots$ & 1,130 & 412 & 74 & 53 & 4.7 & 1,740 & 7.9 & $\ldots$ & $\mathrm{C} 3-\mathrm{S} 2$ \\
\hline 18 & .8 & 4.0 & .06 &.---- & 1,350 & 320 & 0 & 71 & 8.7 & 1,890 & 8.3 & 2.32 & $\mathrm{C} 3-\mathrm{S} 2$ \\
\hline 30 & 1.1 & .4 & $\ldots$ & 1,100 & 1,090 & 248 & 0 & 73 & 8.6 & 1,630 & 7.9 & 6.25 & C3-S2 \\
\hline 8.6 & .9 & .7 & $\ldots$ & 1,080 & 1,070 & 272 & 0 & 69 & 7.6 & 1,590 & 8.0 & 4.77 & $\mathrm{C} 3-\mathrm{S} 2$ \\
\hline 10 & 1.0 & 1.0 & .36 & 1,090 & 1,070 & 223 & 0 & 75 & 9.1 & 1,590 & 8.0 & 4.98 & C3-S2 \\
\hline 9.3 & .7 & 2.3 & .21 & 997 & 994 & 477 & 78 & 42 & 3.2 & 1,430 & 7.8 & 0 & C3-S1 \\
\hline 29 & .3 & 100 & .06 & 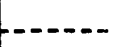 & 1,470 & 664 & 100 & 44 & 4.0 & 1,820 & 7.7 & & C3-S1 \\
\hline 48 & .3 & 149 & .19 & 1,320 & 1,340 & 568 & 206 & 41 & 3.6 & 1,900 & 7.5 & 0 & C3-S1 \\
\hline 30 & .9 & 2.5 & .45 & 2,790 & 2,820 & 536 & 88 & 74 & 14 & 3,700 & 8.1 & 0 & C4-S4 \\
\hline$\cdots$ & -- &.- & $\cdots$ & & 2,970 & 540 & 0 & 73 & 14 & 3,880 & 7.6 & 1.43 & $\mathrm{C} 4-\mathrm{S} 4$ \\
\hline 14 & .7 & 5.6 & .45 & 1,810 & 1,840 & 447 & 0 & 68 & 9.2 & 2,540 & 7.9 & 2.89 & $\mathrm{C} 4-\mathrm{S} 3$ \\
\hline 6.0 & .8 & 4.0 & .27 &.--- & 987 & 414 & 0 & 50 & 4.2 & 1,500 & 7.6 & 2.57 & C3-S1 \\
\hline 30 & .8 & 2.7 & .27 & 2,560 & 2,570 & 679 & 92 & 66 & 10 & 3,340 & 7.9 & 0 & $\mathrm{C} 4-\mathrm{S} 3$ \\
\hline 10 & 1.0 & 2.8 & .22 & 806 & 800 & 312 & 0 & 54 & 4.2 & 1,210 & 8.1 & 1.96 & C3-S1 \\
\hline 7.1 & .6 & .2 & .18 & 642 & 641 & 300 & 0 & 45 & 2.9 & 982 & 7.9 & 1.15 & $\mathrm{C} 3-\mathrm{S} 1$ \\
\hline 26 & .6 & 4.2 & .23 & 2,300 & 2,430 & 1,010 & 555 & 45 & 5.1 & 2,920 & 7.9 & 0 & C4-S2 \\
\hline 48 & .7 & 7.3 & .22 & 3,100 & 3,350 & 1,530 & 1,010 & 38 & 4.9 & 3,710 & 7.7 & 0 & $\mathrm{C} 4-\mathrm{S} 2$ \\
\hline 8.5 & .7 & 1.8 & .21 & 1,460 & 1,460 & 428 & 0 & 64 & 7.5 & 2,090 & 8.0 & 2.98 & C3-S2 \\
\hline.-- & $\ldots$ & $\ldots$ & -- & . & 659 & 198 & 0 & 61 & 4.6 & 1,010 & 7.7 & 1.14 & $\mathrm{C} 3-\mathrm{S} 1$ \\
\hline$\ldots$ & - & -. &.- & 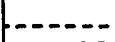 & 652 & 332 & 46 & 38 & 2.3 & 982 & 7.7 & 0 & C3-S1 \\
\hline 8.4 & .6 & .1 & .37 & 765 & 777 & 194 & 0 & 68 & 6.0 & 1,170 & 7.9 & 2.30 & C3-S2 \\
\hline 13 & .6 & .9 & .34 & 997 & 1,020 & 318 & 0 & 60 & 5.5 & 1,480 & 8.1 & .69 & C3-S2 \\
\hline 12 & 0 & 1.8 & .25 & $-\infty$ & 987 & 248 & 0 & 68 & 7.1 & 1,470 & 7.8 & 3.97 & $\mathrm{C} 3-\mathrm{S} 2$ \\
\hline--- & & -- & $-n_{1}$ & 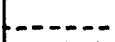 & 1,210 & 280 & 0 & 73 & 8.9 & 1,740 & 8.0 & 7.22 & $\mathrm{C} 3-\mathrm{S} 2$ \\
\hline 12 & .4 & .1 & $\ldots$ & 653 & 636 & 383 & 71 & 32 & 1.8 & 988 & 7.8 & 0 & C3-S1 \\
\hline 8.8 & .6 & .2 & .20 & 682 & 675 & 350 & 0 & 40 & 2.5 & 1,030 & 7.3 & .42 & C3-S1 \\
\hline 9.7 & 1.0 & 1.3 & .59 & 766 & 756 & 131 & 0 & 79 & 8.9 & 1,170 & 7.9 & 6.54 & C3-S2 \\
\hline 16 & .8 & 1.7 & .68 & 925 & 918 & 184 & 0 & 75 & 8.5 & 1,400 & 8.0 & 5.74 & $\mathrm{C} 3-\mathrm{S} 2$ \\
\hline 9.2 & .5 & .1 & .20 & 872 & 889 & 262 & 0 & 63 & 5.8 & 1,350 & 7.8 & 3.63 & C3-S2 \\
\hline 9.6 & .7 & 5.2 & .19 & 974 & 958 & 616 & 0 & 30 & 2.2 & 1,470 & 7.8 & .86 & C3-S1 \\
\hline 21 & .8 & 5.9 & .26 & 1,540 & 1,540 & 700 & 42 & 46 & 4.6 & 2,130 & 8.0 & 0 & C3-S2 \\
\hline 9.0 & .6 & .7 & .12 & 769 & 758 & 516 & 0 & 28 & 1.8 & 1,210 & 7.9 & .96 & C3-S1 \\
\hline 16 & .6 & 13 & .39 & 1,900 & 1,950 & 111 & 0 & 92 & 25 & 2,930 & 8.4 & 8.09 & $\mathrm{C} 4-\mathrm{S} 4$ \\
\hline & & & $\ldots$ & & 740 & 289 & 0 & 53 & 3.8 & 1,120 & 8.1 & 1.61 & C3-S1 \\
\hline 44 & .7 & .4 & .39 & 2,610 & 2,610 & 915 & 207 & 56 & 7.8 & 3,360 & 8.0 & 0 & C4-S2 \\
\hline & & &.-- & $---\cdot-$ & 2,160 & 308 & 0 & 82 & 16 & 3,070 & 8.0 & 9.84 & C4-S4 \\
\hline 6.2 & 1.5 & .4 & & 2,140 & 2,100 & 319 & 0 & 81 & 16 & 3,000 & | 7.8 & 9.62 & C4-S4 \\
\hline
\end{tabular}


Table 2.-Chemical analyses of water from

[Results in parts per mil

\begin{tabular}{|c|c|c|c|c|c|c|c|c|c|c|c|c|c|}
\hline Well number & Depth & $\begin{array}{l}\text { Date of } \\
\text { collection }\end{array}$ & $\begin{array}{l}\text { Tem- } \\
\text { pera- } \\
\text { ture } \\
\left({ }^{\circ} \mathrm{F}\right)\end{array}$ & $\begin{array}{l}\text { Silica } \\
\left(\mathrm{SiO}_{2}\right)\end{array}$ & $\begin{array}{l}\text { Iron } \\
(\mathrm{Fe})\end{array}$ & $\begin{array}{l}\text { Man- } \\
\text { ga- } \\
\text { nese } \\
(\mathrm{Mn})\end{array}$ & $\begin{array}{c}\text { Cal- } \\
\text { cium } \\
(\mathrm{Ca})\end{array}$ & $\begin{array}{c}\text { Mag- } \\
\text { ne- } \\
\text { sium } \\
(\mathrm{Mg})\end{array}$ & $\begin{array}{c}\text { So- } \\
\text { dium } \\
(\mathrm{Na})\end{array}$ & $\begin{array}{l}\text { Po- } \\
\text { tas- } \\
\text { sium } \\
(\mathrm{K})\end{array}$ & $\begin{array}{l}\text { Bicar- } \\
\text { bonate } \\
\left(\mathrm{HCO}_{3}\right)\end{array}$ & $\left.\begin{array}{c}\mathrm{Car}- \\
\text { bon- } \\
\text { ate } \\
\left(\mathrm{CO}_{3}\right)\end{array}\right)$ & $\begin{array}{l}\text { Sul- } \\
\text { fate } \\
\left(\mathrm{SO}_{4}\right)\end{array}$ \\
\hline $27-55-1$ aad 3 & 126 & May 14,1964 & 49 & 25 & 3.2 & & 75 & 33 & 664 & 4.4 & 984 & 0 & 900 \\
\hline $27-56-3 c a b$ & 90 & May 5,1964 & 47 & 18 & .32 & $\ldots$ & 204 & 95 & 448 & 8.2 & 948 & 0 & 1,060 \\
\hline $27-56-5 c d a$ & 157 & Nov. 14, 1963 & 47 & 22 & 7.6 & .12 & 120 & 44 & 495 & 7.2 & 758 & 0 & 890 \\
\hline $27-56-6 b b b$ & 115 & Oct. 3,1962 & & $\ldots$ & $a_{4.0}$ & & 71 & 19 & 495 & $\ldots$ & 735 & 0 & 680 \\
\hline $27-58-35 a a b$ & 55.5 & Sept.20, 1963 & $\ldots$ & 18 & .02 & $\ldots$ & 69 & 24 & 126 & 3.0 & 391 & 0 & 210 \\
\hline $27-58-36 \mathrm{bcd}$ & 80 & Sept.23, 1963 & & 18 & $\ldots$ & & 84 & 33 & 156 & 4.8 & 574 & 0 & 203 \\
\hline $27-58-36 c d b$ & 118 & Sept. 9, 1963 & 49 & 24 & $\ldots$ & --- & 160 & 70 & 384 & 8.6 & 738 & 0 & 875 \\
\hline $28-49-36 \mathrm{caa}$ & 68 & Nov. 6,1963 & 48 & $-\ldots$ & 2.9 & $\ldots$ & $\ldots$ & $\ldots$ & 402 & $\ldots$ & 490 & 0 & 875 \\
\hline $28-49-36 \mathrm{cba}$ & 54.5 & Apr. 30, 1964 & 46 & $\ldots-\ldots$ & $\ldots$ & & $\ldots$. & $\ldots \ldots$ & 4 & 08 & 512 & 0 & 968 \\
\hline $28-51-19 a b b$ & 18 & Sept. 7, 1963 & 47 & 19 & .22 & .03 & 164 & 88 & 244 & 15 & 758 & 0 & 320 \\
\hline $28-53-25 d b$ & 90 & Oct. 14,1947 & 47 & 14 & 3.4 & & 105 & 111 & 697 & 22 & 1,130 & 0 & 1,270 \\
\hline $28-53-29$ dac & 82 & Oct. 5,1963 & 52 & 11 & .09 & .02 & 4.6 & 1.1 & 518 & 1.5 & 1,050 & 32 & 27 \\
\hline $28-53-30$ da 11 & 106 & Oct. 8,1964 & & 12 & .02 & & 30 & 16 & 260 & 1.5 & 620 & 0 & 180 \\
\hline $28-53-32 a d b$ & 88 & Oct. 24,1963 & 49 & $\ldots$ & .30 & & 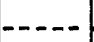 & 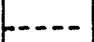 & 550 & & 1,050 & 33 & 6.0 \\
\hline $28-53-32 d c d$ & 100 & Oct. 7,1963 & 51 & $-\ldots$ & & & & & 436 & & 928 & 12 & 71 \\
\hline $28-54-35$ caa 1 & 30 & Sept. 9, 1963 & & 21 & 1.6 & .94 & 185 & 67 & 193 & 6.4 & 576 & 0 & 650 \\
\hline $28-54-35$ caa 2 & 78 & Sept. 9, 1963 & 53 & 7.6 & 2.9 & .11 & 96 & 42 & 118 & 6.8 & 408 & 0 & 323 \\
\hline $28-55-32 a c$ & 100 & Sept. 9,1963 & $\cdots$ & $\ldots$ & $\ldots$ & & $\ldots$ & $-\cdots$ & 469 & $-\ldots$ & 997 & 0 & 1,380 \\
\hline $28-55-33$ dad & 15.3 & Oct. 13,1947 & 45 & 12 & 3.6 & $-\ldots$ & 229 & 103 & 467 & 14 & 1,190 & 0 & 971 \\
\hline $28-56-27 b d$ & 16.3 & Sept.10, 1963 & 49 & 19 & .05 & .17 & 58 & 24 & 61 & 3.1 & 385 & 0 & 60 \\
\hline $28-56-29 a c d$ & 80 & Oct. 12,1964 & 46 & 22 & .02 & & 153 & 71 & 519 & 7.6 & 770 & 0 & 1,110 \\
\hline 28-57-25aca & 147 & Oct. 12,1964 & 47 & 23 & .16 & $\ldots-$ & 75 & 24 & 438 & 10 & 784 & 0 & 548 \\
\hline $28-57-32 d b 1$ & 18.9 & Oct. 13,1947 & 46 & 21 & .10 & & 158 & 59 & 13 & 10 & 351 & 0 & 293 \\
\hline
\end{tabular}

a In solution when analyzed.

Table 3.-Chemical anal [Results in parts per mil

\begin{tabular}{|c|c|c|c|c|c|c|c|c|c|c|c|c|}
\hline Source & $\begin{array}{l}\text { Date or } \\
\text { collection }\end{array}$ & $\begin{array}{l}\text { Tem- } \\
\text { pera- } \\
\text { ture } \\
\left({ }^{\circ} \mathrm{F}\right)\end{array}$ & $\begin{array}{c}\text { Esti- } \\
\text { mated } \\
\text { dis- } \\
\text { charge } \\
\text { (cfs) }\end{array}$ & $\begin{array}{l}\text { Silica } \\
\left(\mathrm{SiO}_{2}\right)\end{array}$ & $\begin{array}{l}\text { Iron } \\
(\mathrm{Fe})\end{array}$ & $\begin{array}{l}\text { Cal- } \\
\text { cium } \\
\text { (Ca) }\end{array}$ & $\begin{array}{l}\text { Mag- } \\
\text { ne- } \\
\text { sium } \\
(\mathrm{Mg})\end{array}$ & $\begin{array}{c}\text { So- } \\
\text { dium } \\
(\mathrm{Na})\end{array}$ & $\begin{array}{l}\text { Po- } \\
\text { tas- } \\
\text { sium } \\
(\mathrm{K})\end{array}$ & $\begin{array}{l}\text { Bicar- } \\
\text { bonate } \\
\left(\mathrm{HCO}_{3}\right)\end{array}$ & $\left.\mid \begin{array}{l}\mathrm{Car}- \\
\text { bon- } \\
\text { ate } \\
\left(\mathrm{CO}_{3}\right)\end{array}\right)$ & $\begin{array}{c}\mathrm{Sul-} \\
\text { fate } \\
\left(\mathrm{SO}_{4}\right)\end{array}$ \\
\hline $\begin{array}{l}\text { Irrigation canal } \\
\quad(26-44-1 \mathrm{ccb})\end{array}$ & Sept. 6, 1963 & 63 & 100 & 8.2 & 0.08 & 56 & 20 & 50 & 4.1 & 189 & 0 & 162 \\
\hline $\begin{array}{l}\text { Irrigation ditch } \\
\quad(27-48-28 d)\end{array}$ & Sept. 6, 1963 & 69 & 80 & & .14 & $\ldots$ & & 53 & & 190 & 0 & 168 \\
\hline $\begin{array}{c}\text { Poplar River } \\
(27-50-1 d)\end{array}$ & Sept. 7, 1963 & 73 & 5 & & & - & & 258 & $\ldots-\cdots$ & 550 & 0 & 177 \\
\hline $\begin{array}{l}\text { Missouri River } \\
(27-55-1 \mathrm{aa})\end{array}$ & May 12,1964 & & & 8.9 & .07 & 59 & 19 & 65 & 4.2 & 189 & 0 & 189 \\
\hline $\begin{array}{l}\text { Big Muddy Creek } \\
(28-55-21 \text { acc })\end{array}$ & Sept. 10, 1963 & 77 & $\ldots$ & & $\ldots$ &.-- & & 341 & & 628 & 0 & 474 \\
\hline
\end{tabular}


selected wells producing from the alluvium-Continued

lion except as indicated]

\begin{tabular}{|c|c|c|c|c|c|c|c|c|c|c|c|c|c|}
\hline \multirow{2}{*}{$\begin{array}{l}\text { Chlo- } \\
\text { ride } \\
\text { (Cl) }\end{array}$} & \multirow{2}{*}{$\begin{array}{l}\text { Fluo- } \\
\text { ride } \\
\text { (F) }\end{array}$} & \multirow{2}{*}{$\begin{array}{l}\mathrm{Ni}- \\
\text { trate } \\
\left(\mathrm{NO}_{3}\right)\end{array}$} & \multirow[b]{2}{*}{$\begin{array}{c}\text { Boron } \\
\text { (B) }\end{array}$} & \multicolumn{2}{|c|}{ Dissolved solids } & \multirow{2}{*}{$\begin{array}{l}\text { Hard- } \\
\text { ness } \\
\text { as } \\
\mathrm{CaCO}_{3}\end{array}$} & \multirow{2}{*}{$\begin{array}{l}\text { Noncar } \\
\text { bonate } \\
\text { hard- } \\
\text { ness as } \\
\mathrm{CaCO} 3\end{array}$} & \multirow{2}{*}{$\begin{array}{c}\text { Per- } \\
\text { cent } \\
\text { so- } \\
\text { dium }\end{array}$} & \multirow{2}{*}{$\begin{array}{c}\text { Sodium } \\
\text { adsorp- } \\
\text { tion } \\
\text { ratio } \\
\text { (SAR) }\end{array}$} & \multirow{2}{*}{$\begin{array}{l}\text { Specific } \\
\text { conduct- } \\
\text { ance } \\
\text { (micro- } \\
\text { mhos per } \\
\mathrm{cm} \text { at } \\
25^{\circ} \mathrm{C} \text { ) }\end{array}$} & \multirow[b]{2}{*}{$\mathrm{pH}$} & \multirow{2}{*}{$\begin{array}{c}\text { Residual } \\
\text { sodium } \\
\text { carbon- } \\
\text { ate } \\
(\text { epm) }\end{array}$} & \multirow{2}{*}{$\begin{array}{l}\text { Irri- } \\
\text { gation } \\
\text { class }\end{array}$} \\
\hline & & & & $\begin{array}{l}\text { Cal- } \\
\text { cu- } \\
\text { lated }\end{array}$ & $\begin{array}{c}\text { Residue } \\
\text { on evap- } \\
\text { oration } \\
\text { at } 180^{\circ} \mathrm{C}\end{array}$ & & & & & & & & \\
\hline 6.8 & 1.6 & .2 & & 2,200 & 2,170 & 323 & 0 & 81 & 16 & 3,030 & 7.8 & 9.67 & C4-S4 \\
\hline 16 & .8 & .1 &.- & 2,320 & 2,330 & 900 & 123 & 52 & 3.2 & 3,050 & 7.5 & 0 & C4-S2 \\
\hline 6.2 & .9 & 7.5 & .23 & 1,970 & 1,970 & 479 & 0 & 69 & 9.8 & 2,690 & 7.4 & 2.84 & C4-S3 \\
\hline 14 & .8 & .5 & $\ldots$ & $\ldots$ & 1,475 & 256 & $\ldots$ & 81 & 13 & $\ldots$ & $\ldots$ & 6.93 & $\ldots$ \\
\hline 8.2 & .7 & .4 & & 651 & 620 & 271 & 0 & 50 & 3.3 & 985 & 7.8 & .99 & $\mathrm{C} 3-\mathrm{S} 1$ \\
\hline 7.8 & .7 & .2 & .18 & 790 & 791 & 344 & 0 & 49 & 3.7 & 1,210 & 7.9 & 2.53 & C3-S1 \\
\hline 15 & .5 & .1 & .20 & 1,900 & 1,890 & 688 & 83 & 54 & 6.4 & 2,550 & 7.7 & 0 & $\mathrm{C} 4-\mathrm{S} 2$ \\
\hline & $\ldots$ & $\ldots$ & $\ldots$ & - & 1,730 & 416 & 14 & 67 & 8.6 & 2,360 & 7.4 & 0 & C4-S2 \\
\hline &.- & $\cdots-\cdots$ &.-- & & 1,840 & 540 & 120 & 62 & 7.6 & 2,520 & 7.8 & 0 & C4-S2 \\
\hline 137 & .5 & 208 & .53 & 1,570 & 1,580 & 769 & 147 & 40 & 3.8 & 2,330 & 8.0 & 0 & C4-S1 \\
\hline 8.0 & .6 & .5 & .36 & & 2,780 & 718 & 0 & 67 & 11 & 3,750 & 7.8 & 4.16 & C4-S3 \\
\hline 112 & 5.4 & .2 & .23 & 1,230 & 1,220 & 16 & 0 & 98 & 56 & 1,990 & 8.5 & 16.89 & C3-S4 \\
\hline 8.5 & 1.0 & 2.6 & .54 & 817 & 820 & 142 & 0 & 80 & 9.5 & 1,280 & 8.1 & 7.32 & C3-S2 \\
\hline$\ldots$ & 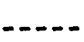 & $\ldots$ & $\ldots$ & $\ldots-\ldots$ & 1,370 & 31 & 0 & 97 & 43 & 2,220 & 8.4 & 16.59 & C3-S4 \\
\hline & $\ldots$ & $\ldots$ & -.... & $\ldots$ & 1,270 & 12 & 0 & 99 & 55 & 1,750 & 8.3 & 14.97 & $\mathrm{C} 3-\mathrm{S} 4$ \\
\hline 20 & .6 & 1.0 & .27 & 1,430 & 1,480 & 739 & 267 & 36 & 3.1 & 1,990 & 7.5 & 0 & C3-S1 \\
\hline 24 & .5 & .0 & .20 & 822 & 855 & 434 & 99 & 37 & 2.5 & 1,280 & 7.4 & 0 & C3-S1 \\
\hline$\ldots$ & $\ldots$ & $\ldots$ &.-- & $\ldots$ & 2,880 & 1,200 & 382 & 45 & 5.9 & 3,490 & 7.4 & 0 & $\mathrm{C} 4-\mathrm{S} 2$ \\
\hline 26 & 0 & 6.2 & .16 & 2,410 & 2,440 & 995 & 19 & 50 & 6.4 & 3,230 & 7.1 & 0 & $\mathrm{C} 4-\mathrm{S} 2$ \\
\hline 2.0 & .3 & 2.3 & .21 & 419 & 410 & 244 & 0 & 35 & 1.7 & 689 & 7.4 & 1.43 & C2-S1 \\
\hline 8.7 & 1.0 & 18 & .37 & 2,290 & 2,280 & 672 & 41 & 62 & 8.7 & 3,000 & 8.0 & 0 & C4-S3 \\
\hline 5.7 & 1.0 & 1.1 & .22 & 1,510 & 1,500 & 285 & 0 & 76 & 11 & 2,160 & 8.0 & 7.15 & C3-S3 \\
\hline 57 & .1 & 6.0 & .16 & $\ldots$ & 829 & 637 & 349 & 4 & .2 & 1,240 & 8.1 & $\ldots$ & $\mathrm{C} 3-\mathrm{S} 1$ \\
\hline
\end{tabular}

yses of surface water

lion except as indicated]

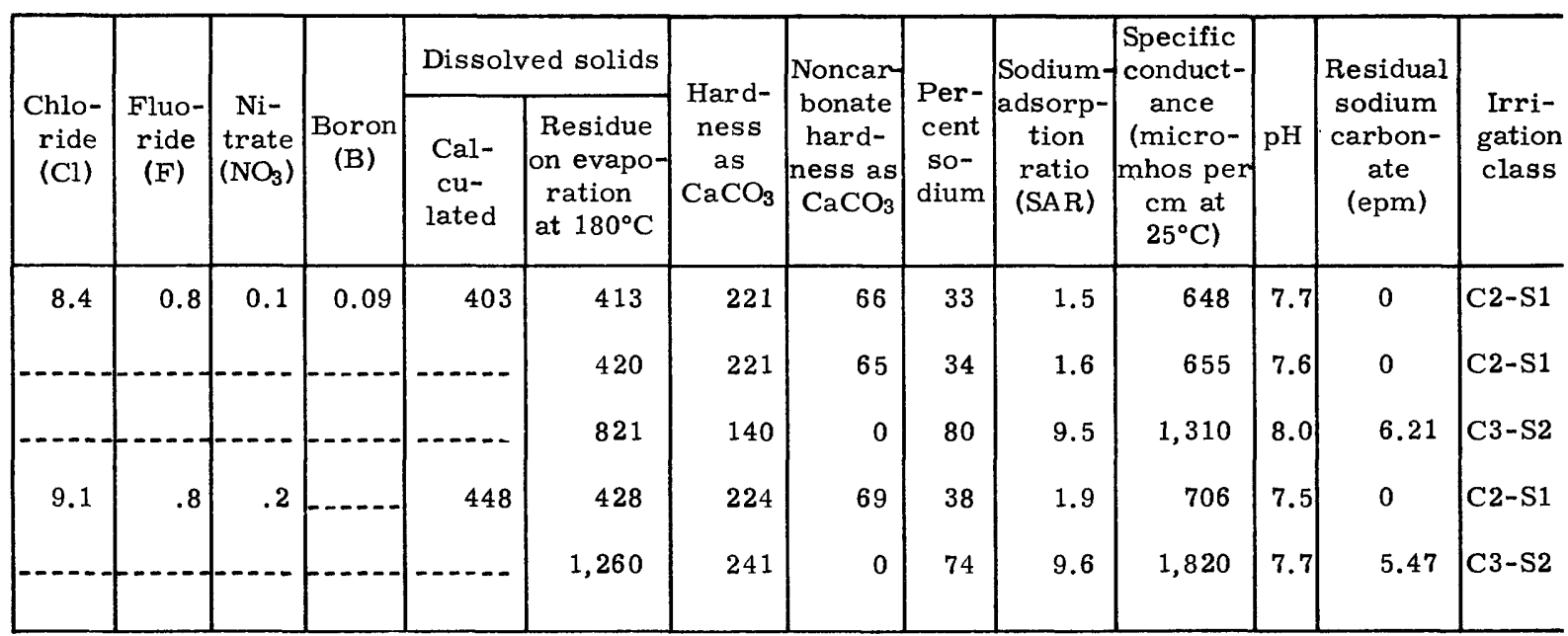




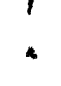

